\title{
Comparative toxicity of ionic and nanoparticulate zinc in the species Cymodoce truncata, Gammarus aequicauda and Paracentrotus lividus
}

\author{
Ermelinda Prato $^{1} \cdot$ Adele Fabbrocini $^{2} \cdot$ Giovanni Libralato $^{3}$ (D) Luciana Migliore $^{4} \cdot$ Isabella Parlapiano $^{1}$. \\ Raffaele D'Adamo ${ }^{2}$. Alice Rotini ${ }^{5} \cdot$ Loredana Manfra $^{5,6}$. Giusy Lofrano ${ }^{7} \cdot$ Federica Carraturo $^{3}$ - Marco Trifuoggi $^{8}$. \\ Francesca Biandolino ${ }^{1}$
}

Received: 20 November 2020 / Accepted: 25 March 2021 / Published online: 7 April 2021

(C) The Author(s) 2021

\begin{abstract}
Due to the continuous development, production and consumption of nanoparticles (NPs), their release, fate and effects in marine coastal environment can represent a major concern. The aim of this study was to evaluate the toxicity of $\mathrm{ZnO}$ nanoparticles $(\mathrm{ZnO}$ NPs) and compare it to bulk $\mathrm{ZnSO}_{4}$ on three macroinvertebrates: the isopod Cymodoce truncata (i.e. used for the first time in ecotoxicology), the amphipod Gammarus aequicauda and the sea urchin Paracentrotus lividus. This study showed concentration- and time-dependent relationships for all biological models for both $\mathrm{ZnO}$ NPs and $\mathrm{ZnSO}_{4}$. Both $\mathrm{Zn}$ forms elicited high toxicity to $G$. aequicauda and $C$. truncata juveniles, but $\mathrm{ZnO}$ NPs induced comparable responses to both species (96h-LC ${ }_{50}$ $=0.30$ and $0.37 \mathrm{mg} / \mathrm{L}$ for $G$. aequicauda and $C$. truncata, respectively; $p>0.05$ ), while differences were found after $\mathrm{ZnSO}_{4}$ exposure $\left(96 \mathrm{~h}-\mathrm{LC}_{50}=0.28\right.$ and $0.63 \mathrm{mg} / \mathrm{L}$, respectively; $\left.p<0.05\right)$. ZnO NPs generated sub-lethal effects on $P$. lividus embryos $\left(72 \mathrm{~h}-\mathrm{EC}_{50}=0.04(0.03,0.05) \mathrm{mg} / \mathrm{L}\right)$, not significantly different from $\mathrm{ZnSO}_{4}$ ones $\left(72 \mathrm{~h}-\mathrm{EC}_{50}=0.06(0.05,0.07) \mathrm{mg} / \mathrm{L}\right) . \mathrm{Effects}$ of $\mathrm{ZnO}$ NPs were similar to existing literature data for other testing species. C. truncata can be considered as a promising new biological model in (nano)ecotoxicology.
\end{abstract}

Keywords Nano-ecotoxicology $\cdot$ Zinc oxide nanoparticles $\cdot$ Zinc sulphate $\cdot$ Crustaceans $\cdot$ Sea urchins

Responsible Editor: Philipp Gariguess

\section{Highlights}

- Short-term toxicity effects were similar for organisms exposed to $\mathrm{ZnO}$

$\mathrm{NPs}$ and $\mathrm{ZnSO}_{4}$.

- Relative sensitivity was found to be in the following order: P. lividus

embryos $>$ G. aequicauda $\approx C$. truncata $>$ P. lividus sperm.

- Toxicity was both concentration- and time-dependent.

Ermelinda Prato

linda.prato@irsa.cnr.it

$\triangle$ Giovanni Libralato

giovanni.libralato@unina.it

1 CNR-IRSA National Research Council - Water Research Institute, Taranto, Italy

2 CNR-ISMAR (National Research Council - Institute of Marine Sciences, Naples, Italy

3 Department of Biology, University of Naples Federico II, Complesso Universitario di Monte Sant'Angelo, Via Cinthia 21,

80126 Naples, Italy
4 Department of Biology, Tor Vergata University of Rome, Rome, Italy

5 Institute for Environmental Protection and Research (ISPRA), Rome, Italy

6 Department of Marine Biotechnology, Stazione Zoologica Anton Dohrn, Naples, Italy

7 Centro Servizi Metrologici e Tecnologici Avanzati (CeSMA), Complesso Universitario di Monte Sant'Angelo, Via Cinthia 21, 80126 Naples, Italy

8 Department of Chemical Sciences, University of Naples Federico II, Complesso Universitario di Monte Sant'Angelo, Via Cinthia 21, 80126 Naples, Italy 


\section{Introduction}

The production and use of engineered metal oxide nanoparticles (NPs) exponentially increased in the last decade because of their unique properties (small size, large surface area, surface reactivity, charge, shape, media interactions) that make them suitable for a wide variety of applications. These include the so-called environmentally friendly nanotechnologies, like commercial products for domestic and healthcare use, and constitute products for waste remediation, fuel and energy production (Lofrano et al. 2017). Among them, zinc oxide nanoparticles ( $\mathrm{ZnO} \mathrm{NPs}$ ) are the third highest used metalcontaining nanomaterials with an estimated annual global production ranging from 550 to 1600 tons/year (Peng et al. 2017; Piccinno et al. 2012; Sun et al. 2014). Their introduction in different materials demonstrated to provide a better alternative in many commercial processes by producing more durable ceramics, transparent solar filter blocking infrared and ultraviolet radiation and reducing the amount of $\mathrm{ZnO}$ in the production of paints, plastic, pigments and catalysts (Nemček et al. 2020; Piccinno et al. 2012). ZnO NPs are also useful in biomedical research since they exhibited selective toxicity for human cancer cell lines and thus are reported as potential 'tools' in chemotherapy (Jiang et al. 2018). ZnO NPs may also be toxic for some microorganisms, making them potential antibacterial, antifungal and antiviral agents, so they are utilized as disinfectant in aquaculture (Khosravi-Katuli et al. 2017); however, an opposite effect may occasionally happen when ZnO NPs enter wastewater streams at treatment plants and inhibit bacterial activities in the activated sludge, affecting negatively treatment efficiency (Tan et al. 2015).

Zinc oxide NPs have been deemed as 'extremely toxic' to aquatic organisms (Kahru and Dubourguier 2010), their toxicity being frequently imputed to the dissolution of $\mathrm{ZnO}$ NPs into toxic and bioavailable zinc forms (i.e. $\mathrm{Zn}$ ions free or weakly complexed with inorganic or organic ligands) (Aruoja et al. 2009; Yung et al. 2015). Moreover, ZnO NPs toxicity may be also due to free radical formation and induction of oxidative stress with the generation of reactive oxygen species (ROS), able to induce DNA (Bai et al. 2010; Zhao et al. 2013), protein, lipid and tissue (Khosravi-Katuli et al. 2018) damage. In addition, the direct interaction between NPs and cells or organisms may cause mechanical damage like shortening and collapsing of gill secondary lamellae in adult fish (Khosravi-Katuli et al. 2018). NPs can also bind to different ligands and acquire several different coatings often within a small period of time, which makes measuring them even harder especially in terms of shape, size and concentration (Diegoli et al. 2008; Nowack and Bucheli 2007; Tiede et al. 2008). Nevertheless, according to the available data, the predicted average environmental concentration of $\mathrm{ZnO}$ NPs in European surface waters is of $0.1 \mathrm{mg} / \mathrm{L}$ (Sun et al. 2014; Tan et al. 2015).
The presence of NPs in marine systems, in particular $\mathrm{ZnO}$ NPs, is a great concern, and the optimization of easy-toperform and quick-response tools specifically tailored to evaluate their effects represents a mandatory issue. The ecotoxicological effects of $\mathrm{ZnO}$ NPs have been investigated by acute toxicity tests on a wide number of freshwater organisms, including bacteria (Sirelkhatim et al. 2015), algae (Franklin et al. 2007), crustaceans (Prato et al. 2020; Vimercati et al. 2020; Wang et al. 2009) and fish (Khosravi-Katuli et al. 2018). Studies on $\mathrm{ZnO}$ NPs ecotoxicity have been performed also on marine organisms belonging to different taxonomic groups, including microalgae, molluscs, crustaceans and fishes (Abdel-Khalek 2015; Fairbairn et al. 2011; Minetto et al. 2016; Prato et al. 2020; Schiavo et al. 2018; Vimercati et al. 2020; Wong et al. 2010).

Crustaceans are among the most common model organisms in acute ecotoxicity assays. They play a key role in the marine food webs and their energy flow, acting as both prey and predator at various trophic levels, frequently in the sedimentary facies, thus being a potential target of NPs (Prato et al. 2020). Among them, members of the Gammaridae family are often utilized to assess ecotoxicity due to their sensitivity and availability in the area, such as Gammarus aequicauda (Prato et al. 2013, 2015), which is why we chose it for the present study. This species plays an important role both in the trophic web and in the organic matter recycling of underlying sediment (Cottiglia et al. 1983). Isopods also are important keystone species in marine ecosystems, but their sensitivity to contaminants is hitherto little studied (Prato et al. 2006), although they are relevant models in soil ecotoxicology. No ecotoxicological data exists on Cymodoce truncata (Leach, 1814), so this is the first study using juveniles of $C$. truncata for toxicity testing. It usually thrives in coastal marine or brackish waters inhabiting seaweed fronds (i.e. haloresistant mesograzer) between 5 and $80 \mathrm{~cm}$ depth.

Sea urchins are a commonly used model organisms for laboratory research; their gametes and embryos have been exposed to a wide range of environmental contaminants, and the consequent alterations at the morphological, physiological and gene expression levels have been studied (Fabbrocini and D'Adamo 2011; Ruocco et al. 2017). Thus, sea urchins are well-established models in ecotoxicological studies (ASTM 2004), and among the Mediterranean species, Paracentrotus lividus has been standardized for ecotoxicity testing since a long time (Arizzi Novelli et al. 2006) involving alterations of sperm motility and early embryo-larval development as endpoints.

The aim of this research was to compare the toxic effects of $\mathrm{ZnO}$ NPs with those of the soluble zinc salt, $\mathrm{ZnSO}_{4}$, in acute ecotoxicological tests with two crustaceans $(C$. truncata and G. aequicauda) and the echinoderm $P$. lividus. These species can be considered of high interest in nanoecotoxicology: both C. truncata and G. aequicauda are bottom filter feeders and 
deposit feeders; thus, they can be potentially at high risk of exposure in nature, due to the tendency of NPs to aggregate in seawater settling down and accumulating in sediment (Garner and Keller 2014); equally, P. lividus, releasing gametes in the water column, where fertilization and larval development occur (Boudouresque and Verlaque 2013), may be exposed to NP contamination in these pivotal phases of the biological cycle.

\section{Materials and methods}

\section{Preparation and characterization of testing media}

Water-dispersed ZnO NPs (20 wt\%, purity of 99.95\%) (S1) were purchased from US Research Nanomaterials, Inc. (Houston, USA) with a nominal particle size of 30-40 nm. A stock suspension $(1000 \mathrm{mg} / \mathrm{L})$ of $\mathrm{ZnO}$ NPs (S2) was prepared in $0.22-\mu \mathrm{m}$ filtered ultrapure water from $\mathrm{S} 1$ and sonicated for $15 \mathrm{~min}$ in a ultrasonic water bath $(305 \mathrm{~W}, 50-60 \mathrm{~Hz}$; Soltec Ultrasonic Baths) and stored in the dark at $4{ }^{\circ} \mathrm{C}$ for 15 $\mathrm{min}$. Final testing suspensions were prepared in filtered (GF/C Whatman, $0.22 \mu \mathrm{m}$ ) natural seawater (FNSW) collected from the Mar Grande of Taranto (Ionian Sea, Italy; $40^{\circ} 25^{\prime} 0.1^{\prime \prime} \mathrm{N}$, $\left.17^{\circ} 14^{\prime} 24^{\prime \prime} \mathrm{E} ; \mathrm{pH} 8.0 \pm 0.1\right)$.

A stock solution of $\mathrm{ZnSO}_{4}$ (Sigma-Aldrich, Germany, $\geq$ $99.9 \%)(1000 \mathrm{mg} / \mathrm{L})$ was prepared by dissolving the toxicant in $0.22-\mu \mathrm{m}$ FNSW, stirring until complete dissolution and stored in the dark at $4{ }^{\circ} \mathrm{C}$. Final testing solution concentrations were prepared in FNSW at the same nominal concentrations of $\mathrm{ZnO} \mathrm{NP}$ suspensions.

The size distribution of $\mathrm{Zn}$ in both solutions and suspensions was carried out using a dynamic light scattering (DLS) composed by a Photocor compact goniometer, a SMD 6000 Laser Quantum 50-mW light source operating at $5325 \AA$ and a photo-multiplier tube (PMT, PMT-120-OP/B) and correlator (Flex02-01D) purchased from Correlator.com. The hydrodynamic radius was evaluated through the StokesEinstein equation (Mangiapia et al. 2013). Each measurement was performed in triplicate. The samples $(1 \mathrm{mg} / \mathrm{L})$ were prepared from a starting solution $(1 \mathrm{~g} / \mathrm{L})$ produced with $0.22-\mu \mathrm{m}$ FNSW and sonicated at $100 \mathrm{~W}$ for three cycles of 5 min each, leaving to rest the sample for $5 \mathrm{~min}$ between two cycles. Finally, each sample was left to equilibrate in the instrument for $15 \mathrm{~min}$ before the measurement. Exclusively in the case of $\mathrm{ZnO} \mathrm{NPs}$, size distribution was followed from $15 \mathrm{~min}$ after sonication until $48 \mathrm{~h}$ of ageing in FNSW.

The size of the ZnO NPs was evaluated by mean of transmission electron microscopy (Lattemann and Höpner 2008) using a Philips EM 208S with an accelerating voltage of 100 $\mathrm{kV}$. All details about ZnO NPs' characterization have been already published in (Prato et al. 2020).
The concentration of $\mathrm{Zn}$ from $\mathrm{ZnSO}_{4}$ and $\mathrm{ZnO} \mathrm{NP}$ solution/suspensions was quantified by inductively coupled plasma mass spectrometry (Aurora M90 Bruker, USA) (Table 1). The detection (LOD $=0.02 \mu \mathrm{g} / \mathrm{L}$ ) and quantification $(\mathrm{LOQ}=0.04 \mu \mathrm{g} / \mathrm{L})$ limits were calculated using the method of blank variability for each investigated metal (EPA 2014).

\section{Chemical analysis and NP characterization}

The nominal and measured concentrations of $\mathrm{Zn}$ in testing suspensions/solutions are reported in Table 1, for ZnO NPs' and $\mathrm{ZnSO}_{4}$ tests. The NP characterization, as already reported by (Prato et al. 2020), demonstrated that the hydrodynamic radius distribution for $\mathrm{ZnSO}_{4}$ solutions was $950 \pm 50 \mathrm{~nm}$, while in $\mathrm{ZnO} N \mathrm{NP}$ suspensions, two peaks (at $150 \pm 20 \mathrm{~nm}$ and $640 \pm 30 \mathrm{~nm}$ ) were found to be related to the production of aggregates. Nevertheless, TEM analysis showed NPs ranging between 10 and $20 \mathrm{~nm}$. According to Prato et al. (2020), the average dissolution of $\mathrm{ZnO} N \mathrm{NPs}$ was $46 \%$ (ranging from

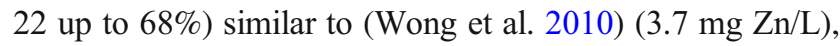
confirming the suitability of the prepared suspensions/ solutions.

\section{Toxicity testing}

\section{C. truncata and G. aequicauda}

Isopods were collected from an unpolluted area located in the Taranto Gulf (Ionian Sea, Southern Italy; 40 49' 63" N, $17^{\circ}$ $32^{\prime} 35^{\prime \prime} \mathrm{E}$ ), used as a local reference site because of the low levels of anthropogenic pollution (unpublished data). Juveniles were collected from the macroalgae Chaetomorpha linum and Ulva sp., transported to the laboratory and placed in culture tanks filled with FNSW $(0.45 \mu \mathrm{m}$ and $36 \pm 2 \mathrm{PSU}$ ), which was continuously aerated and maintained at $18 \pm 2{ }^{\circ} \mathrm{C}$ with a $12: 12 \mathrm{~h}$ light/dark cycle. Both species were acclimated to the above experimental conditions for at least 7-10 days after field collection. During the acclimation period, C. truncata and G. aequicauda were fed weekly with the seaweed Chaetomorpha linum, and benthic microalgae Phaeodactylum tricornutum were added to the tanks to integrate the organic matter present in the native sediment.

Juveniles of C. truncata and G. aequicauda were utilized in a semi-static acute toxicity test (i.e. suspensions/solutions were renewed after $48 \mathrm{~h}$ ). They were exposed for $96 \mathrm{~h}$ in triplicate to $0.12,0.25,0.50,1.00$ and $2.00 \mathrm{mg} / \mathrm{L}$ (nominal concentrations) of test suspensions/solutions, including a negative control (FNSW) (Table 1). For isopod species, twenty individuals per concentration were randomly selected from the culture tanks and added to a $250-\mathrm{mL}$ glass beaker containing $200 \mathrm{~mL}$ of test suspension/solution. Test species were not 
Table 1 Nominal and measured total $\mathrm{Zn}$ concentration in $\mathrm{ZnO} N P s$ and $\mathrm{ZnSO}_{4}$ testing suspensions/solutions and control (filtered natural seawater, FN $\mathrm{SW}$; as mean values \pm standard deviation, $n=3$ per testing suspensions/solutions and seawater)

\begin{tabular}{|c|c|c|c|c|}
\hline \multirow{2}{*}{$\begin{array}{l}\text { Zn concentrations } \\
(\mathrm{mg} / \mathrm{L})\end{array}$} & \multicolumn{2}{|c|}{ C. truncata and G. aequicauda } & \multicolumn{2}{|l|}{ P. lividus } \\
\hline & Nominal & Measured & Nominal & Measured \\
\hline FNSW & - & $0.001 \pm 0.00$ & - & $0.001 \pm 0.00$ \\
\hline \multirow[t]{6}{*}{$\mathrm{ZnO}$ NPs } & 0.12 & $0.11 \pm 0.00$ & 0.01 & $0.02 \pm 0.00$ \\
\hline & 0.25 & $0.23 \pm 0.05$ & 0.05 & $0.06 \pm 0.00$ \\
\hline & 0.5 & $0.48 \pm 0.09$ & 0.1 & $0.11 \pm 0.00$ \\
\hline & 1 & $0.85 \pm 0.17$ & 0.2 & $0.16 \pm 0.03$ \\
\hline & 2 & $1.26 \pm 0.25$ & 0.5 & $0.48 \pm 0.09$ \\
\hline & & & 1 & $0.85 \pm 0.17$ \\
\hline \multirow[t]{6}{*}{$\mathrm{ZnSO}_{4}$} & 0.12 & $0.15 \pm 0.05$ & 0.01 & $0.02 \pm 0.00$ \\
\hline & 0.25 & $0.28 \pm 0.05$ & 0.05 & $0.04 \pm 0.00$ \\
\hline & 0.5 & $0.52 \pm 0.10$ & 0.1 & $0.15 \pm 0.05$ \\
\hline & 1 & $0.93 \pm 0.08$ & 0.2 & $0.30 \pm 0.07$ \\
\hline & 2 & $1.73 \pm 0.35$ & 0.5 & $0.52 \pm 0.10$ \\
\hline & & & 1 & $0.93 \pm 0.08$ \\
\hline
\end{tabular}

fed during the testing period. Water quality parameters (temperature, $\mathrm{pH}$, dissolved oxygen and salinity) were measured at the beginning and at the end of each test to check quality assurance and quality control (ISO 16712:2005). Mortality was checked daily, and dead animals were removed; missing animals were considered dead; apparently dead individuals were considered living if movement was exhibited after gentle stimulation. At the end of the experiments, the surviving organisms were counted. The mortality threshold value was $10 \%$ in negative controls for the above toxicity tests (USEPA 1994).

\section{P. lividus}

Adult sea urchins ( 35 to $45 \mathrm{~mm}$ in diameter without spines) were hand-collected with the aid of scuba diving equipment along the southern Adriatic coast of Italy (Termoli, CB; $41^{\circ}$ $\left.54^{\prime} \mathrm{N}, 16^{\circ} 10^{\prime} \mathrm{E}\right)$. Collected specimens were placed in a cooler and carried to the laboratory under moist conditions for no more than $2 \mathrm{~h}$. Sea urchins were then placed in a recirculating aquarium and reared as described in (Fabbrocini and D'Adamo 2011) until gamete collection. Sea urchins were induced to spawn by injection of $1 \mathrm{~mL}$ of $\mathrm{KCl} 0.5 \mathrm{M}$. Gametes were observed by microscope, and the best male and female samples were selected for the pools (at least three individuals for each pool). The sperm pools were dry stored at $4{ }^{\circ} \mathrm{C}$, while the eggs were gently washed in FNSW and kept at $18^{\circ} \mathrm{C}$. Embryotoxicity test was performed within $1 \mathrm{~h}$ of gamete collection. The embryotoxicity test was carried out as described in (Fabbrocini and D'Adamo 2011). Fertilized eggs were incubated at a final concentration of $200 \mathrm{eggs} / \mathrm{mL}$ in $10-$ $\mathrm{ml}$ polystyrene multiwell plates containing the test solutions $(0.01,0.05,0.10,0.20,0.50,1.00 \mathrm{mg} / \mathrm{L}$ of $\mathrm{ZnO} \mathrm{NPs}$ and $\mathrm{ZnSO}_{4}$ in FNSW), until plutei larvae were obtained $(72 \mathrm{~h}$, $18{ }^{\circ} \mathrm{C}$, in the dark). Samples were preserved in concentrated buffered formalin, and the percentages of normal developed plutei (NPL) were scored by observing 200 larvae for each sample. FNSW was used as a negative control, while scaled concentrations of copper were used for the positive control. The effects of ZnO NPs were evaluated on sperm cell motility according to the MOT-test (Fabbrocini et al. 2010). Sperm samples were diluted at a ratio of 1:1000 in 0.01, 0.05, 0.10, $0.20,0.50,1.00,5.0$ and $10.0 \mathrm{mg} / \mathrm{L}$ of $\mathrm{ZnO} N \mathrm{NPs}$ and $\mathrm{ZnSO}_{4}$ in FNSW and incubated for $60 \mathrm{~min}$ at $18{ }^{\circ} \mathrm{C}$. On dilution and after incubation, sperm motility was evaluated by computerized motion analysis system, the Sperm Class Analyzer ${ }^{\circledR}$ (SCA, Microptic, s.l., Spain). The following motion parameters were assessed: (a) total motile sperm (TM), as the percentage of sperm with a curvilinear velocity $>10 \mu \mathrm{m} / \mathrm{sec}$ ); (b) rapid sperm (RAP), as the percentage of sperm with a curvilinear velocity $>100 \mu \mathrm{m} / \mathrm{sec}$ ); (c) curvilinear velocity (VCL, $\mu \mathrm{m} / \mathrm{sec}$ ); (d) amplitude of lateral head displacement (ALH, $\mu \mathrm{m})$; and (e) beat-cross frequency (BCF, Hz). FNSW was used as a negative control, while scaled concentrations of cadmium were used for the positive control.

\section{Statistical analysis}

All experiments were repeated three times in triplicate, and data were recorded as the mean with standard deviation (SD). For crustaceans, the 24, 48, 72 and $96 \mathrm{~h}$ median lethal concentration values $\left(\mathrm{LC}_{50}\right)$ and related $95 \%$ confidence 
limits were calculated using the Litchfield-Wilcoxon method. For $P$. lividus, the median effective concentrations $\left(\mathrm{EC}_{50}\right)$ were determined using the Trimmed Spearman-Karber statistical method. Prior to processing, all data were adjusted according to Abbott's formula (ASTM 2004). The one-way analysis of variance (ANOVA) was used to detect statistical significance of the differences between the control and treated groups, and post hoc Tukey's test was used to discriminate between results' pair. When data failed to meet the assumption of normality and homoscedasticity, the non-parametric Kruskal-Wallis test was used to compare individual treatments. A two-way ANOVA with Tukey's post hoc test was applied to detect significant effects of the parameter time (exposure period) and concentration $(p<0.05)$. All statistical analyses were conducted using Past3 Version 1.0 software.

\section{Results}

\section{Toxicity to crustaceans}

The negative controls showed mortality $<10 \%$ for both species. The $96 \mathrm{~h}-\mathrm{LC}_{50}$ values for $\mathrm{ZnO}$ NPs exposure were 0.37 and $0.30 \mathrm{mg} / \mathrm{L}$ for C. truncata and G. aequicauda, respectively. The exposure to $\mathrm{ZnSO}_{4}$ produced significantly higher $\mathrm{LC}_{50}$ values for $C$. truncata $(0.63 \pm 0.09 \mathrm{mg} / \mathrm{L})$ than for G. aequicauda $(0.28 \pm 0.04 \mathrm{mg} / \mathrm{L})(p<0.05)$ (Table 2$)$. Nevertheless, no significant differences between $\mathrm{ZnO}$ NPs and $\mathrm{ZnSO}_{4}$ toxicity were found between testing species at the considered exposure times.

The concentration-response curves at different exposure times (Fig. 1) for both crustaceans (see also Tables S1-S2, Supplementary Materials, summarizing the results of a twoway ANOVA on exposure time and concentration) evidenced that mortality increased with increasing exposure time for both $\mathrm{ZnO} N P s$ and $\mathrm{ZnSO}_{4}$. Both species showed similar mortality trends after exposure to both $\mathrm{Zn}$ forms, although $\mathrm{ZnSO}_{4}$ seemed a little more toxic than $\mathrm{ZnO}$ NPs. After 96-h exposure, C. truncata seemed less susceptible to ZnO NPs at the lowest concentrations tested, although G. aequicauda showed very low mortality at the shortest time exposure $(24 \mathrm{~h})$. In this species, the exposure time seemed more important than in C. truncata, with the mortality rates quite different at different times. Nevertheless, at the highest concentration after 96-h exposure, mortality was approximately $100 \%$ in all experimental batches.

\section{Toxicity to echinoderm}

The effects of echinoderm sperm and embryo exposure to $\mathrm{ZnO}$ NPs and $\mathrm{ZnSO}_{4}$ on a multiple endpoints basis are shown in Fig. 2. Normal development of plutei larvae (NPL), total motility of sperms (TM), entity of rapid sperm population (RAP), curvilinear velocity (VCL), lateral head displacement $(\mathrm{ALH})$ and beat-cross frequency of flagellum (BCF) are reported.

A clear dose-response was observed in the embryotoxicity test (NPL endpoint), where a $100 \%$ alteration was found at concentrations $\geq 0.2 \mathrm{mg} / \mathrm{L}$ for both $\mathrm{ZnO} \mathrm{NPs}$ and $\mathrm{ZnSO}_{4}$, with calculated $\mathrm{EC}_{50}$ of $0.04 \pm 0.008 \mathrm{mg} / \mathrm{L}$ and $0.06 \pm 0.03 \mathrm{mg} / \mathrm{L}$, respectively.

Conversely, none of the multi-endpoints of the motility parameters (MOT-tests) showed a clear concentration-effect response; hence, $\mathrm{EC}_{50}$ was not calculated. In detail, no adverse effects on the percentage of motile sperm (TM) or on the consistence of the sub-population of rapid sperm (RAP) were observed after $1 \mathrm{~h}$ of exposure to $\mathrm{ZnO} \mathrm{NP}$ suspensions up to $10 \mathrm{mg} / \mathrm{L}$; nevertheless, toxic effects were observed for the VCL endpoint (up to 40\%) and for the ALH and BCF ones (up to 20\%), although the Tukey's post hoc tests did not highlight significant differences among concentrations. Similarly, the exposure to $\mathrm{ZnSO}_{4}$ up to $5 \mathrm{mg} / \mathrm{L}$ scarcely affected all the motility endpoints (always $<20 \%$ ), although significant differences among $\mathrm{ZnSO}_{4}$ concentration were observed. On the

Table $2 \mathrm{LC}_{50}$ values $(\mathrm{mg} / \mathrm{L})$ for C. truncata, G. aequicauda and $\mathrm{EC}_{50}$ P. lividus embryos exposed to $\mathrm{ZnO} \mathrm{NPs} \mathrm{and} \mathrm{ZnSO}_{4}$ (as mean values \pm standard deviation; $n=3$ per species per $\mathrm{Zn}$ form)

\begin{tabular}{|c|c|c|c|c|c|}
\hline Endpoints & Time & Compounds & C. truncata & G. aequicauda & P. lividus \\
\hline \multirow[t]{2}{*}{$\mathrm{LC}_{50}$} & \multirow[t]{2}{*}{$24 \mathrm{~h}$} & $\mathrm{ZnO}$ NPs & $0.95 \pm 0.11$ & n.a. & n.a. \\
\hline & & $\mathrm{ZnSO}_{4}$ & $1.37 \pm 0.15$ & n.a. & n.a. \\
\hline $\mathrm{LC}_{50}$ & $48 \mathrm{~h}$ & $\begin{array}{l}\mathrm{ZnO} N \mathrm{NPs} \\
\mathrm{ZnSO}_{4}\end{array}$ & $\begin{array}{l}0.74 \pm 0.16 \\
1.07 \pm 0.05\end{array}$ & $\begin{array}{l}0.76 \pm 0.04 \\
0.78 \pm 0.14\end{array}$ & $\begin{array}{l}\text { n.a. } \\
\text { n.a. }\end{array}$ \\
\hline \multirow[t]{2}{*}{$\mathrm{LC}_{50} / \mathrm{EC}_{50}$} & \multirow[t]{2}{*}{$72 \mathrm{~h}$} & $\mathrm{ZnO}$ NPs & $0.56 \pm 0.22$ & $0.40 \pm 0.04$ & $0.04 \pm 0.008$ \\
\hline & & $\mathrm{ZnSO}_{4}$ & $0.80 \pm 0.11$ & $0.39 \pm 0.06$ & $0.06 \pm 0.003$ \\
\hline $\mathrm{LC}_{50}$ & $96 \mathrm{~h}$ & $\begin{array}{l}\mathrm{ZnO} N P s \\
\mathrm{ZnSO}_{4}\end{array}$ & $\begin{aligned} 0.37 & \pm 0.07 \\
0.63 & \pm 0.09\end{aligned}$ & $\begin{array}{l}0.30 \pm 0.06 \\
0.28 \pm 0.04\end{array}$ & $\begin{array}{l}\text { n.a. } \\
\text { n.a. }\end{array}$ \\
\hline
\end{tabular}

n.a., not available 
Fig. 1 Relationship between concentration and mortality in C. truncata (a and b) and G. aequicauda (c and d) exposed to $\mathrm{ZnO} N \mathrm{Ns}_{\mathrm{s}}$ or $\mathrm{ZnSO}_{4}$ for 24 to $96 \mathrm{~h}$ (as mean mortality values \pm standard deviation; $n=9$ per species and per $\mathrm{Zn}$ form; post hoc Tukey's test results in Table S1, Supplemental Material); data were normalized to negative controls

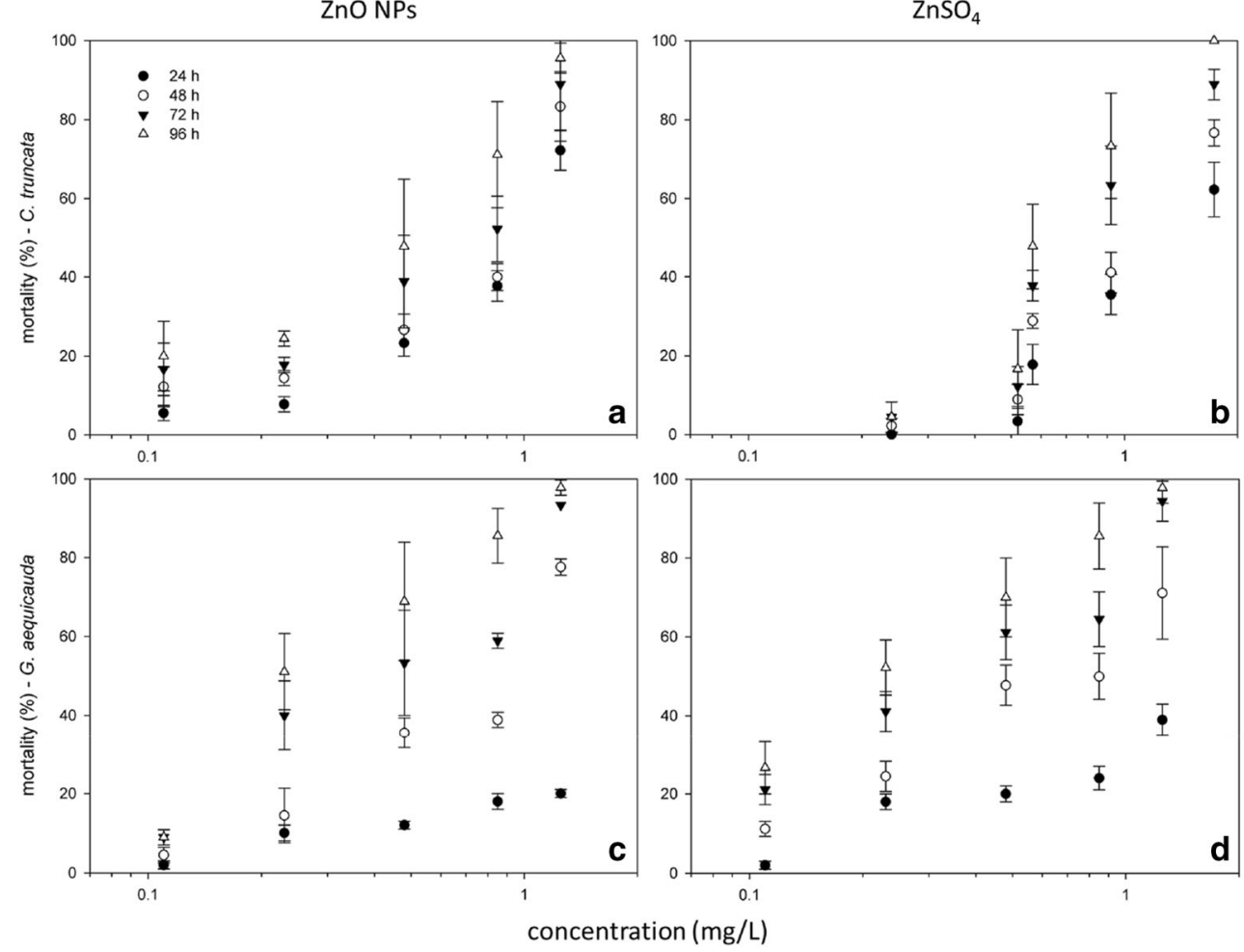

contrary, the sperm cell suspensions exposed to $10 \mathrm{mg} / \mathrm{L}$ $\mathrm{ZnSO}_{4}$ highlighted a significant reduction of RAP, VCL and BCF endpoints (70, 55 and $45 \%$, respectively) but no effect on TM and ALH ones.

\section{Discussion and conclusions}

The bioassays with $C$. truncata and $G$. aequicauda assessed $\mathrm{ZnO} \mathrm{NP}$ toxicity in comparison to $\mathrm{ZnSO}_{4}$. The bioassay with C. truncata is brand new and demonstrated its effectiveness to evaluate NPs toxicity. These results did not highlight significant differences between the two $\mathrm{Zn}$ forms but between the two species of crustaceans. The bioassay on P. lividus embryos did not show differences between the two $\mathrm{Zn}$ forms, both eliciting quite high toxicity. Hence, the order of decreasing toxicity for both $\mathrm{ZnO} N \mathrm{NP}$ and $\mathrm{ZnSO}_{4}$ obtained from this study is $P$. lividus $>G$. aequicauda $\approx C$. truncata. The comparable toxicity of $\mathrm{ZnO}$ NPs and its bulk form can be imputed to the high dissolution rate of ZnO NPs (46\%; see Chemical analysis and NP characterization) as already demonstrated by Prato et al. (2020) with direct measure of the concentration of dissolved $\mathrm{Zn}$ ions in the experimental medium or in filtered $\mathrm{ZnO}$ NP suspensions and the findings of comparable toxicity of $\mathrm{ZnO}$ NPs and the relative bulk forms $\left(\mathrm{ZnCl}_{2}\right.$ or $\left.\mathrm{ZnSO}_{4}\right)$. Prato et al. (2020) stated that the dissolution of ZnO NPs in FNSW depended on their concentrations. Our experimental design included a range of concentrations of ZnO NPs that can be deemed as rapidly and completely solubilized. Data are in agreement with those of Fairbairn et al. (2011), showing an almost complete dissolution within $10-20 \mathrm{~h}$ at 0.1 and $1 \mathrm{mg} / \mathrm{L}$, although at higher $\mathrm{ZnO} N P$ concentration $(10 \mathrm{mg} / \mathrm{L})$, a slower dissolution rate was found (i.e. after the first $24 \mathrm{~h}$ ) (Fairbairn et al. 2011). The contribution of dissolved $\mathrm{Zn}^{2+}$ ions to the ecotoxicity of $\mathrm{ZnO}$ NPs is considered pivotal by Aruoja et al. 2009; Blinova et al. 2010; Fairbairn et al. 2011; and Wong et al. 2010, ascribing the toxic effect of ZnO NPs mainly to the $\mathrm{Zn}^{2+}$ ion dissolution.

In the literature, we could not find references for $\mathrm{ZnO} N \mathrm{NP}$ ' and $\mathrm{ZnSO}_{4}$ toxicity in the tested crustaceans; particularly, no data on $C$. truncata are available, and few studies utilized marine isopods as a model species in ecotoxicological study, although they are relevant models in soil ecotoxicology.

Data on ZnO NP toxicities are available for several other crustaceans: in the freshwater D. magna (Muna et al. 2019) (Heinlaan et al. 2008) calculated a $48 \mathrm{~h} \mathrm{LC}_{50}$ of 3.2 and 2.6 $\mathrm{mg} / \mathrm{L}$, respectively; in the same studies, the $\mathrm{LC}_{50}$ for T. platyurus was calculated as 0.18 and $0.14 \mathrm{mg} / \mathrm{L}$, respectively. Both studies demonstrated that $\mathrm{Zn}^{2+}$ ions were responsible of the $\mathrm{ZnO}$ NP toxicity, found in the test media at concentrations ranging from $40 \mu \mathrm{g} / \mathrm{L}$ to $58 \mathrm{mg} / \mathrm{L}$. In the marine copepod Tigriopus japonicus and in the amphipod Elasmopus rapax nauplii, the $\mathrm{ZnO} \mathrm{NP}$ ecotoxicity tests demonstrated that $\mathrm{ZnO}$ NPs $(26.2 \pm 5.1 \mathrm{~nm}$, mean diameter $)$ were more toxic to T. japonicus than to E. rapax (Wong et al. 2010). Furthermore, Fabrega et al. 2012) highlighted that the chronic 
Fig. 2 Percentage of effects (mean \pm standard deviation; $n=3$ ) on a multi-endpoint basis (normal developed plutei larvae (NPL), total motile sperm (TM), rapid sperm (RAP), curvilinear velocity (VCL), lateral head displacement (ALH) and beat-cross frequency (BCF)) in P. lividus sperm cells and embryos exposed to $\mathrm{ZnO} \mathrm{NPs}$ and $\mathrm{ZnSO}_{4}$. Data with different letters (a-d) are significantly different (Tukey's test, $p<0.05$ ); data were normalized to negative controls
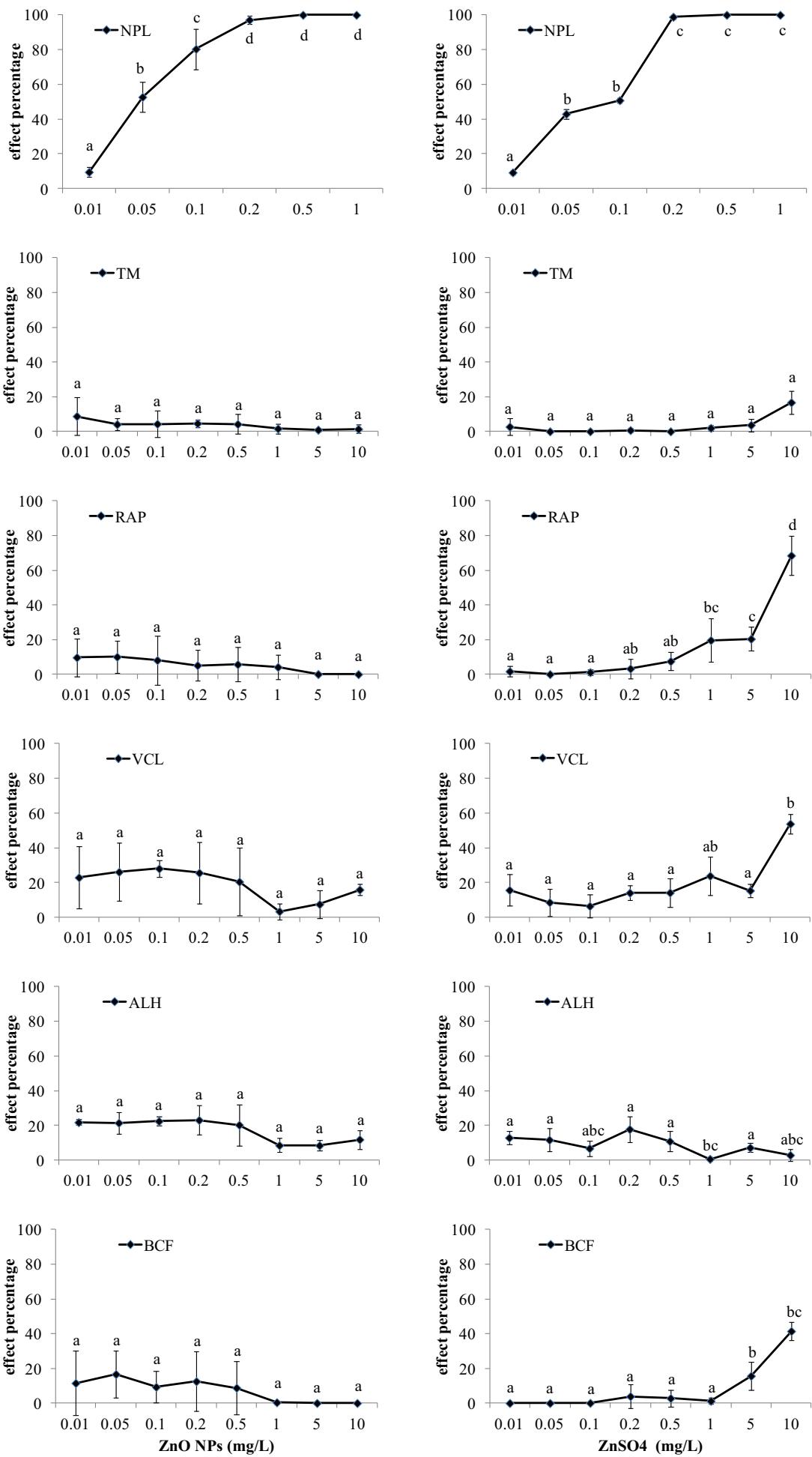

exposure to $\mathrm{ZnO}$ NPs $(35 \pm 10 \mathrm{~nm}$, mean diameter at $1 \mathrm{mg} / \mathrm{L})$ can significantly affect the survival, growth and reproduction of Corophium volutator. It is worth to note that toxicity data of $\mathrm{ZnO}$ NPs and $\mathrm{ZnSO}_{4}$ are often based only on nominal concentrations (Vimercati et al. 2020), without taking into consideration the possible different effects of the high ionic strength of the saline medium on NPs (in the case of marine tests) as well as their sedimentation rate or shielding effect (i.e. reduction of the repulsive force among NPs due to their relative charge) (Rotini et al. 2017).

Due to the rapid and wide solubilization of ZnO NPs at the concentrations used in this study, the sea urchin sperms and 
embryos have been exposed to solubilized $\mathrm{Zn}^{2+}$ throughout the entire assay, and, consequently, the toxicity of ZnO NPs may be largely attributed to the dissolution of $\mathrm{Zn}$ ions into seawater. Motile sperm tests did not show a clear concentration-response when exposed to ZnO NP suspensions, only VCL (curvilinear velocity) being slightly affected by the exposure, while the other endpoints as lateral head displacement (ALH, depending on active sperm motility) and beat-cross frequency (BCF, depending on the flagellar beating) (Gallego et al. 2014; van der Horst et al. 2018) seemed not affected, indicating no clear alteration of both the structural integrity of the sperm cell and to the physiology of sperm movement.

The results obtained in this study are in agreement with those of Ozgur et al. (2018), who found that C. carpio spermatozoa exposed to $\mathrm{ZnO}$ NPs were slightly affected, with significant alteration only on VCL and BCF. The limited effect of $\mathrm{ZnO}$ NPs and $\mathrm{ZnSO}_{4}$ on P. lividus sperm motility is also consistent with the slight effect on fertilization found by Manzo et al. (2013) for the same species. The exposure of sea urchin embryos to $\mathrm{ZnO} N$ Ps or $\mathrm{ZnSO}_{4}$ produced similar $\mathrm{EC}_{50}$ values $(p>0.05)$, further involving ionic zinc as responsible of the toxicity. The results on embryotoxicity agree with previous studies. Manzo et al. (2013) found 100\% of P. lividus abnormal plutei larvae after exposure to $0.06-\mathrm{mg} / \mathrm{L} \mathrm{ZnO} \mathrm{NPs}$, and Fairbairn et al. (2011) found $100 \%$ of abnormal plutei in Lytechinus pictus exposed to $0.15 \mathrm{mg} / \mathrm{L} \mathrm{ZnO}$ NPs. Mos et al. (2017) and Smital and Kurelec (1998) observed only $10 \%$ of normal gastrulae in Tripneustes gratilla exposed to $0.1-\mathrm{mg} / \mathrm{L}$ $\mathrm{ZnO}$ NPs. Similarly, the $\mathrm{EC}_{50}$ values in P. lividus embryos exposed to $\mathrm{ZnSO}_{4}$ are comparable to those found for L. pictus (Fairbairn et al. 2011) and for P. lividus (Arizzi Novelli et al. 2003). Soluble $\mathrm{Zn}$ ions can cause abnormal morphology in embryos of the sea urchin L. pictus embryos after $96 \mathrm{~h}$ (Fairbairn et al. 2011), but they also hindered growth, delaying sexual maturation and affecting reproduction in the amphipod C. volutator at concentrations ranging between 0.2 and $1 \mathrm{mg} / \mathrm{L}$ under chronic exposure (100 days) (Fabrega et al. 2012). Conversely, Zhu et al. (2009) observed lower toxicity of $\mathrm{Zn}^{2+}$ than $\mathrm{ZnO}$ NPs on Danio rerio embryos and stated that $\mathrm{ZnO}$ NPs may produce more ROS than $\mathrm{Zn}^{2+}$ at least in freshwater impairing the antioxidant defence system. This hypothesis has been confirmed on different organisms, the marine algae Thalassiosira pseudonana, Skeletonema marinoi, Dunaliella tertiolecta and Isochrysis galbana by Miller et al. (2010) who imputed the toxic effect of ZnO NPs to the adsorption of particles onto the cell surface, damaged by both the NP production of ROS and the dissolved of $\mathrm{Zn}$ ions. Hence, the toxic effects of ZnO NPs cannot be only explained by the zinc ion action, but they must be linked to the physicochemical nature of the nanoparticles, such as their size. For example, at a concentration of $100 \mathrm{mg} / \mathrm{L}, \mathrm{ZnO}$ NPs of $10-30 \mathrm{~nm}$ size are significantly more toxic than $\mathrm{ZnO}$ NPs of $200 \mathrm{~nm}$ to the brine shrimp Artemia salina (26\% vs $18 \%$ mortality; after 96 h) (Ates et al. 2013; Libralato 2014). As a last point, the toxicity of $\mathrm{ZnO}$ NPs might be also caused by mechanical injury to the organisms, as happens in the marine copepod $T$. japonicus damaged by $\mathrm{ZnO}$ NP aggregates attached to the exoskeleton (Wong et al. 2010).

In conclusion, this study demonstrated the toxicity of $\mathrm{ZnO}$ NPs (according to concentration and exposure time) towards two marine crustaceans, C. truncata and G. aequicauda, and their feasibility as model species for NP studies. Toxicity has been found comparable to $\mathrm{ZnSO}_{4}$ one, suggesting a role of dissolved $\mathrm{Zn}$ ions in the toxicity of $\mathrm{ZnO} \mathrm{NP}$, although other possible mechanisms of toxicity for the NPs have to be considered. Furthermore, being isopods relevant model organisms in other environmental compartment, the newly tested species, C. truncata, seemed to present promising characteristics as a new potential easy-to-use testing species. Further focused studies should be carried out about. The study also highlighted the ecotoxicity of ZnO NPs to the sperm and developing embryos of the sea urchin $P$. lividus. Although a direct quantification of ZnO NPs in the marine environments is difficult to obtain, according to model-based estimates, it should range from hundreds $\mathrm{ng} / \mathrm{L}$ to about $900 \mu \mathrm{g} / \mathrm{L}$ (Yung et al. 2015); therefore, the effects on different developmental endpoints even at low concentrations highlight the toxicity of these contaminants to sea urchin embryos, probably elicited also in the field.

This study prompts the urgency of monitoring $\mathrm{ZnO}$ NPs in the marine environment because of their potential effects on sensitive species providing a first set of data about concentration- and time-response relationships. Special attention should be devoted to the molecular mechanisms of the considered biological models to better investigate the action of both $\mathrm{ZnO}$ NPs and their dissolved forms, as already done for $\mathrm{CuO}$ NPs (Gallo et al. 2018). This may help the understanding of $\mathrm{ZnO}$ NPs' environmental implications for the saltwater compartment supporting the process for the identification of environmental quality benchmarks.

Supplementary Information The online version contains supplementary material available at https://doi.org/10.1007/s11356-021-13712-0.

Author contributions EP, conceptualization, data analysis and paper drafting; AF, sea urchin toxicity testing; GL, paper drafting and statistical analyses; LM, crustacean toxicity testing and paper drafting; IP, crustacean toxicity testing; RDA, sea urchin toxicity testing; AR, crustacean toxicity testing; LuMi, crustacean toxicity testing and paper drafting; GL, statistical analysis and paper drafting; FC, chemical analysis; MT, chemical analysis assessment; FB, conceptualization, data analysis and paper drafting. All authors read and approved the final manuscript.

Funding Open access funding provided by Università degli Studi di Napoli Federico II within the CRUI-CARE Agreement. 
Availability of data and materials All data generated or analysed during this study are included in this published article and its supplementary information files.

\section{Declarations}

Ethics approval and consent to participate Not applicable.

Consent for publication Not applicable.

Competing interests The authors declare no competing interests.

Open Access This article is licensed under a Creative Commons Attribution 4.0 International License, which permits use, sharing, adaptation, distribution and reproduction in any medium or format, as long as you give appropriate credit to the original author(s) and the source, provide a link to the Creative Commons licence, and indicate if changes were made. The images or other third party material in this article are included in the article's Creative Commons licence, unless indicated otherwise in a credit line to the material. If material is not included in the article's Creative Commons licence and your intended use is not permitted by statutory regulation or exceeds the permitted use, you will need to obtain permission directly from the copyright holder. To view a copy of this licence, visit http://creativecommons.org/licenses/by/4.0/.

\section{References}

Abdel-Khalek AA (2015) Risk assessment, bioaccumulation of metals and histopathological alterations in Nile tilapia (Oreochromis niloticus) facing degraded aquatic conditions. Bull Environ Contam Toxicol 94:77-83

Arizzi Novelli A, Losso C, Ghetti PF, Ghirardini AV (2003) Toxicity of heavy metals using sperm cell and embryo toxicity bioassays with Paracentrotus lividus (Echinodermata: Echinoidea): comparisons with exposure concentrations in the lagoon of Venice, Italy. Environ Toxicol Chem 22:1295-1301

Arizzi Novelli A, Losso C, Libralato G, Tagliapietra D, Pantani C, Ghirardini AV (2006) Is the 1:4 elutriation ratio reliable? Ecotoxicological comparison of four different sediment:water proportions. Ecotoxicol Environ Saf 65:306-313

Aruoja V, Dubourguier H-C, Kasemets K, Kahru A (2009) Toxicity of nanoparticles of $\mathrm{CuO}, \mathrm{ZnO}$ and $\mathrm{TiO} 2$ to microalgae Pseudokirchneriella subcapitata. Sci Total Environ 407:1461-1468

ASTM E (2004) Standard Guide for Conducting Short-Term Chronic Toxicity Tests with Echinoid Embryos

Ates M, Daniels J, Arslan Z, Farah IO (2013) Effects of aqueous suspensions of titanium dioxide nanoparticles on Artemia salina: assessment of nanoparticle aggregation, accumulation, and toxicity. Environ Monit Assess 185:3339-3348

Bai W, Zhang Z, Tian W, He X, Ma Y, Zhao Y, Chai Z (2010) Toxicity of zinc oxide nanoparticles to zebrafish embryo: a physicochemical study of toxicity mechanism. J Nanopart Res 12:1645-1654

Blinova I, Ivask A, Heinlaan M, Mortimer M, Kahru A (2010) Ecotoxicity of nanoparticles of $\mathrm{CuO}$ and $\mathrm{ZnO}$ in natural water. Environ Pollut 158:41-47

Boudouresque CF, Verlaque M (2013) Paracentrotus lividus. In Developments in Aquaculture and Fisheries Science. Elsevier 38: 297-327

Cottiglia M, Tagliasacchi Masala M, Serra E (1983) Relations trophiques dans une lagune littorale tyrrhenienne. Rapp Comm Int Mer Medit $28: 151-153$
Diegoli S, Manciulea AL, Begum S, Jones IP, Lead JR, Preece JA (2008) Interaction between manufactured gold nanoparticles and naturally occurring organic macromolecules. Sci Total Environ 402:51-61

EPA (2014) Method SW 6020b: Inductively coupled plasma mass spectrometry. Environmental Protection Agency, Washington

Fabbrocini A, D'Adamo R (2011) Gametes and embryos of sea urchins (Paracentrotus lividus, Lmk., 1816) reared in confined conditions: their use in toxicity bioassays. Chem Ecol 27:105-115

Fabbrocini A, Di Stasio M, D’Adamo R (2010) Computerized sperm motility analysis in toxicity bioassays: a new approach to pore water quality assessment. Ecotoxicol Environ Saf 73:1588-1595

Fabrega J, Tantra R, Amer A, Stolpe B, Tomkins J, Fry T, Lead JR, Tyler CR, Galloway TS (2012) Sequestration of zinc from zinc oxide nanoparticles and life cycle effects in the sediment dweller amphipod Corophium volutator. Environ Sci Technol 46:1128-1135

Fairbairn EA, Keller AA, Mädler L, Zhou D, Pokhrel S, Cherr GN (2011) Metal oxide nanomaterials in seawater: linking physicochemical characteristics with biological response in sea urchin development. J Hazard Mater 192:1565-1571

Franklin NM, Rogers NJ, Apte SC, Batley GE, Gadd GE, Casey PS (2007) Comparative toxicity of nanoparticulate $\mathrm{ZnO}$, bulk $\mathrm{ZnO}$, and $\mathrm{ZnCl} 2$ to a freshwater microalga (Pseudokirchneriella subcapitata): the importance of particle solubility. Environ Sci Technol 41:8484-8490

Gallego V, Pérez L, Asturiano J, Yoshida M (2014) Sperm motility parameters and spermatozoa morphometric characterization in marine species: a study of swimmer and sessile species. Theriogenology 82 : $668-676$

Gallo A, Manfra L, Boni R, Rotini A, Migliore L, Tosti E (2018) Cytotoxicity and genotoxicity of $\mathrm{CuO}$ nanoparticles in sea urchin spermatozoa through oxidative stress. Environ Int 118:325-333

Garner KL, Keller AA (2014) Emerging patterns for engineered nanomaterials in the environment: a review of fate and toxicity studies. J Nanopart Res 16:2503

Heinlaan M, Ivask A, Blinova I, Dubourguier H-C, Kahru A (2008) Toxicity of nanosized and bulk $\mathrm{ZnO}, \mathrm{CuO}$ and $\mathrm{TiO} 2$ to bacteria Vibrio fischeri and crustaceans Daphnia magna and Thamnocephalus platyurus. Chemosphere 71:1308-1316

ISO (2005) Water quality - Determination of acute toxicity of marine or estuarine sediment to amphipods

Jiang J, Pi J, Cai J (2018) The advancing of zinc oxide nanoparticles for biomedical applications. Bioinorganic chemistry and applications, 2018. Article ID 1062562

Kahru A, Dubourguier H-C (2010) From ecotoxicology to nanoecotoxicology. Toxicology 269:105-119

Khosravi-Katuli K, Prato E, Lofrano G, Guida M, Vale G, Libralato G (2017) Effects of nanoparticles in species of aquaculture interest. Environ Sci Pollut Res 24:17326-17346

Khosravi-Katuli K, Lofrano G, Pak Nezhad H, Giorgio A, Guida M, Aliberti F, Siciliano A, Carotenuto M, Galdiero E, Rahimi E, Libralato $\mathrm{G}$ (2018) Effects of $\mathrm{ZnO}$ nanoparticles in the Caspian roach (Rutilus rutilus caspicus). Sci Total Environ 626:30-41

Lattemann S, Höpner T (2008) Environmental impact and impact assessment of seawater desalination. Desalination 220:1-15

Libralato G (2014) The case of Artemia spp. in nanoecotoxicology. Mar Environ Res 101:38-43

Lofrano G, Libralato G, Brown J (2017) Nanotechnologies for Environmental Remediation. Springer International Publishing

Mangiapia G, Vitiello G, Irace C, Santamaria R, Colonna A, Angelico R, Radulescu A, D'Errico G, Montesarchio D, Paduano L (2013) Anticancer cationic ruthenium nanovectors: from rational molecular design to cellular uptake and bioactivity. Biomacromolecules 14 : 2549-2560

Manzo S, Miglietta ML, Rametta G, Buono S, Di Francia G (2013) Embryotoxicity and spermiotoxicity of nanosized $\mathrm{ZnO}$ for 
Mediterranean sea urchin Paracentrotus lividus. J Hazard Mater 254: $1-9$

Miller RJ, Lenihan HS, Muller EB, Tseng N, Hanna SK, Keller AA (2010) Impacts of metal oxide nanoparticles on marine phytoplankton. Environ Sci Technol 44:7329-7334

Minetto D, Volpi Ghirardini A, Libralato G (2016) Saltwater ecotoxicology of $\mathrm{Ag}, \mathrm{Au}, \mathrm{CuO}, \mathrm{TiO}<\mathrm{inf}>2</ \mathrm{inf}>, \mathrm{ZnO}$ and $\mathrm{C}<\mathrm{inf}>60</ \mathrm{inf}>$ engineered nanoparticles: an overview. Environ Int 92-93:189-201

Mos B, Kaposi KL, Rose AL, Kelaher B, Dworjanyn SA (2017) Moderate ocean warming mitigates, but more extreme warming exacerbates the impacts of zinc from engineered nanoparticles on a marine larva. Environ Pollut 228:190-200

Muna M, Blinova I, Kahru A, Vinković Vrček I, Pem B, Orupõld K, Heinlaan M (2019) Combined effects of test media and dietary algae on the toxicity of $\mathrm{CuO}$ and $\mathrm{ZnO}$ nanoparticles to freshwater microcrustaceans Daphnia magna and Heterocypris incongruens: food for thought. Nanomaterials 9:23

Nemček L, Šebesta M, Urík M, Bujdoš M, Dobročka E, Vávra I (2020) Impact of bulk $\mathrm{ZnO}, \mathrm{ZnO}$ nanoparticles and dissolved $\mathrm{Zn}$ on early growth stages of barley - a pot experiment. Plants 9:1365

Nowack B, Bucheli TD (2007) Occurrence, behavior and effects of nanoparticles in the environment. Environ Pollut 150:5-22

Ozgur ME, Ulu A, Balcioglu S, Ozcan I, Okumuş F, Koytepe S, Ates B (2018) Investigation of toxicity properties of flower-like $\mathrm{ZnO}$ nanoparticles on Cyprinus carpio sperm cells using computer-assisted sperm analysis (CASA). Turk J Fish Aquat Sci 18:771-780

Peng C, Zhang W, Gao H, Li Y, Tong X, Li K, Zhu X, Wang Y, Chen Y (2017) Behavior and potential impacts of metal-based engineered nanoparticles in aquatic environments. Nanomaterials 7:21

Piccinno F, Gottschalk F, Seeger S, Nowack B (2012) Industrial production quantities and uses of ten engineered nanomaterials in Europe and the world. J Nanopart Res 14:1109

Prato E, Di Leo A, Biandolino F, Cardellicchio N (2006) Sediment toxicity tests using two species of marine amphipods: Gammarus aequicauda and Corophium insidiosum. Bull Environ Contam Toxicol 76(4):629-636

Prato E, Parlapiano I, Biandolino F (2013) Assessment of individual and combined toxicities of three heavy metals $(\mathrm{Cu}, \mathrm{Cd}$ and $\mathrm{Hg})$ by using Tigriopus fulvus. Chem Ecol 29:635-642

Prato E, Biandolino F, Libralato G (2015) A toxicity scoring system for the 10-day whole sediment test with Corophium insidiosum (Crawford). Environ Monit Assess 187:1-11

Prato E, Parlapiano I, Biandolino F, Rotini A, Manfra L, Berducci MT, Maggi C, Libralato G, Paduano L, Carraturo F, Migliore L (2020) Chronic sublethal effects of $\mathrm{ZnO}$ nanoparticles on Tigriopus fulvus (Copepoda, Harpacticoida). Environmental Science and Pollution Research 27(25):30957-30968

Rotini A, Tornambè A, Cossi R, Iamunno F, Benvenuto G, Berducci MT, Maggi C, Thaller MC, Cicero AM, Manfra L (2017) Salinity-based toxicity of $\mathrm{CuO}$ nanoparticles, $\mathrm{CuO}$-bulk and $\mathrm{Cu}$ ion to Vibrio anguillarum. Front Microbiol 8:2076

Ruocco N, Fedele AM, Costantini S, Romano G, Ianora A, Costantini M (2017) New inter-correlated genes targeted by diatom-derived polyunsaturated aldehydes in the sea urchin Paracentrotus lividus. Ecotoxicol Environ Saf 142:355-362

Schiavo S, Oliviero M, Li J, Manzo S (2018) Testing ZnO nanoparticle ecotoxicity: linking time variable exposure to effects on different marine model organisms. Environ Sci Pollut Res 25:4871-4880

Sirelkhatim A, Mahmud S, Seeni A, Kaus NHM, Ann LC, Bakhori SKM, Hasan H, Mohamad D (2015) Review on zinc oxide nanoparticles: antibacterial activity and toxicity mechanism. Nano Micro Lett 7: 219-242

Smital T, Kurelec B (1998) The chemosensitizers of multixenobiotic resistance mechanism in aquatic invertebrates: a new class of pollutants. Mutat Res 399:43-53

Sun TY, Gottschalk F, Hungerbühler K, Nowack B (2014) Comprehensive probabilistic modelling of environmental emissions of engineered nanomaterials. Environ Pollut 185:69-76

Tan M, Qiu G, Ting Y-P (2015) Effects of ZnO nanoparticles on wastewater treatment and their removal behavior in a membrane bioreactor. Bioresour Technol 185:125-133

Tiede K, Boxall AB, Tear SP, Lewis J, David H, Hassellöv M (2008) Detection and characterization of engineered nanoparticles in food and the environment. Food Addit Contam 25:795-821

USEPA (1994) Methods for assessing the toxicity of sediment-associated contaminants with estuarine and marine amphipods. Office of Research and Development, Washington DC

van der Horst G, Bennett M, Bishop JD (2018) CASA in invertebrates. Reprod Fertil Dev 30:907-918

Vimercati L, Cavone D, Caputi A, De Maria L, Tria M, Prato E, Ferri GM (2020) Nanoparticles: an experimental study of zinc nanoparticles toxicity on marine crustaceans. General overview on the health implications in humans. Front Public Health 8:192

Wang H, Wick RL, Xing B (2009) Toxicity of nanoparticulate and bulk $\mathrm{ZnO}, \mathrm{Al} 2 \mathrm{O} 3$ and $\mathrm{TiO} 2$ to the nematode Caenorhabditis elegans. Environ Pollut 157:1171-1177

Wong SW, Leung PT, Djurišić A, Leung KM (2010) Toxicities of nano zinc oxide to five marine organisms: influences of aggregate size and ion solubility. Anal Bioanal Chem 396:609-618

Yung MM, Wong SW, Kwok KW, Liu F, Leung Y, Chan W, Li X, Djurišić A, Leung KM (2015) Salinity-dependent toxicities of zinc oxide nanoparticles to the marine diatom Thalassiosira pseudonana. Aquat Toxicol 165:31-40

Zhao L, Hernandez-Viezcas JA, Peralta-Videa JR, Bandyopadhyay S, Peng B, Munoz B, Keller AA, Gardea-Torresdey JL (2013) ZnO nanoparticle fate in soil and zinc bioaccumulation in corn plants (Zea mays) influenced by alginate. Environ Sci Process Impacts 15:260-266

Zhu X, Wang J, Zhang X, Chang Y, Chen Y (2009) The impact of ZnO nanoparticle aggregates on the embryonic development of zebrafish (Danio rerio). Nanotechnology 20:195103

Publisher's note Springer Nature remains neutral with regard to jurisdictional claims in published maps and institutional affiliations. 